\title{
North Atlantic sea-floor spreading rates: implications for the Tertiary development of inversion structures of the Norwegian-Greenland Sea
}

\author{
JON MOSAR ${ }^{1}$, GAVIN LEWIS ${ }^{2} \&$ TROND H. TORSVIK ${ }^{3,4}$ \\ ${ }^{1}$ Département de Géosciences de l'Université, Géologie et Paléontologie, Pérolles, Ch du Musée 6, CH-1700 Fribourg, \\ Switzerland (e-mail: jon.mosar@unifr.ch) \\ ${ }^{2}$ Norsk Chevron, Karenslyst Alle 2, Skøyen, 0212 Oslo, Norway \\ ${ }^{3}$ VISTA, c/o Geological Survey of Norway, Leif Eirikssons vei 39, N-7491 Trondheim, Norway \\ ${ }^{4}$ Institute of Petroleum Technology and Applied Geophysics, NTNU, N-7494 NTNU, Norway
}

\begin{abstract}
The Tertiary development of the Norwegian continental margin was dominated by the opening of the Arctic-North Atlantic Ocean. The correct identification of magnetic anomalies and their ages and the analysis of spreading rates during the formation of this ocean are important in understanding the development of the region and specifically the history of its passive margins. Three ocean domains, the Ægir, Reykjanes and Mohns regions, were investigated in an effort to understand the lateral changes in structural development of the passive margin after continental break-up. Spreading rates generally slowed down from $2 \mathrm{~cm} \mathrm{a}^{-1}$ after Early Eocene initiation of sea-floor spreading, to values around $0.5 \mathrm{~cm} \mathrm{a}^{-1}$ in Oligocene time. An increase in spreading rates to around $1 \mathrm{~cm} \mathrm{a}^{-1}$ coincided with the positioning of the Iceland hotspot under the North Atlantic mid-ocean ridge. At the same time, the European plate changed its absolute plate motion from a north-directed drift to a motion more towards the east. The location of inversion structures in the Vøring and Faeroes Basin rather than in the Møre Basin is related to differences in spreading rates. The Mohns and the Reykjanes Ridges produced more ocean floor than the Ægir-Kolbeinsey Ridges. Asymmetric ocean-floor formation in the Ægir Ridge led to differential stress at the base of the lithosphere, which probably explains the absence of inversion features in the Møre Basin (less mantle drag). Furthermore, upper plate margins such as the Vøring Basin and possibly the Faeroe Basin have a lower compressional strength than lower plate margins such as the Møre Basin, and therefore preferentially developed inversion structures. Along the transform boundaries separating the domains, additional stress probably built up along extension of the transform zones into the extended continental crust. This additional stress probably also assisted initiation of the inversion structures in the Vøring Basin and the Faeroes area. The amplification of the inversion structures in the Vøring Basin and the Faeroes Basin was subsequently caused by a variety of processes related to sedimentation and uplift-erosion.
\end{abstract}

Keywords: Norwegian Sea, Tertiary, sea-floor spreading, passive margins, inversion tectonics.

The Mid-Norwegian continental shelf has been extensively studied (Parker 1993; Fleet \& Boldy 1999; Nøttvedt 2000), and the generally accepted model involves multiphase rifting culminating in Early Eocene crustal separation of Greenland and Norway and the opening of the NE Atlantic Ocean (Vogt 1986a, 1986b; Brekke \& Riis 1987; Ziegler 1988; Doré 1991, 1992; Torske \& Prestvik 1991; Skogseid et al. 1992a, 1992b; Skogseid 1994; Lundin \& Doré 1997; Brekke et al. 1999, 2001; Doré et al. 1999). Major rift events occurred in Late Carboniferous, Permian-Triassic, Late Jurassic-Early Cretaceous and Late Cretaceous-Early Tertiary time with the locus of crustal strain migrating towards the future zone of crustal separation (Doré 1992; Doré et al. 1997; Walker et al. 1997; Swiecicki et al. 1998; Spencer et al. 1999; Brekke 2000; Reemst \& Cloetingh 2000; Brekke et al. 2001). This multiphase rifting led to the formation of distinct structural domains along the passive margin (Figs. 1 and 2; Vogt 1986a, 1986b; Blystad et al. 1995; Doré \& Lundin 1996; Brekke et al. 1999; Doré et al. 1999; Brekke 2000; Mosar 2000; Skogseid et al. 2000). The style of the Late Jurassic rift was characterized by the rotated fault blocks of the Halten Terrace. Although extensional faulting during Permo-Carboniferous time affected a much broader area, maximum subsidence occurred during Early and Late Cretaceous time, as witnessed by the formation of the Vøring and Møre Basins. Tertiary inversion, which will be discussed extensively in this paper, caused uplift centred around the areas of maximum Late Cretaceous to Early Tertiary extension (Figs. 1 and 2).

The oceanic lithosphere between Mid-Norway and Greenland can be subdivided into three main domains (Fig. 2) based upon large-scale transfer zones, as follows. (1) The extinct Ægir Ridge spreading system, situated west of the Møre Basin (Skogseid \& Eldholm 1987; Grevemeyer et al. 1997), is delimited to the NW by the Jan Mayen microcontinent (Kuvaas \& Kodaira 1997), which separates the currently active Kolbeinsey Ridge spreading system from the Ægir Ridge (Applegate 1997). (2) The Mohns Ridge system of the Greenland Sea is located WNW of the Vøring Basin and Trøndelag Platform. This ridge system is limited to the SSW by the Jan Mayen Transfer Zone (JMTZ), which separates it from the Ægir Ridge and Kolbeinsey Ridge systems. The JMTZ also partly forms the boundary between the Vøring Basin to the north and the Møre Basin to the south. (3) The Reykjanes Ridge system to the SSW, west of the FaeroeShetland Basin and SSW of Iceland, is separated from the Ægir Ridge system by the Iceland-Faeroe Ridge (Figs. 1 and 2).

The Vøring and Møre Marginal Highs form the outermost zones of the extended Norwegian continental crust, to the west of 

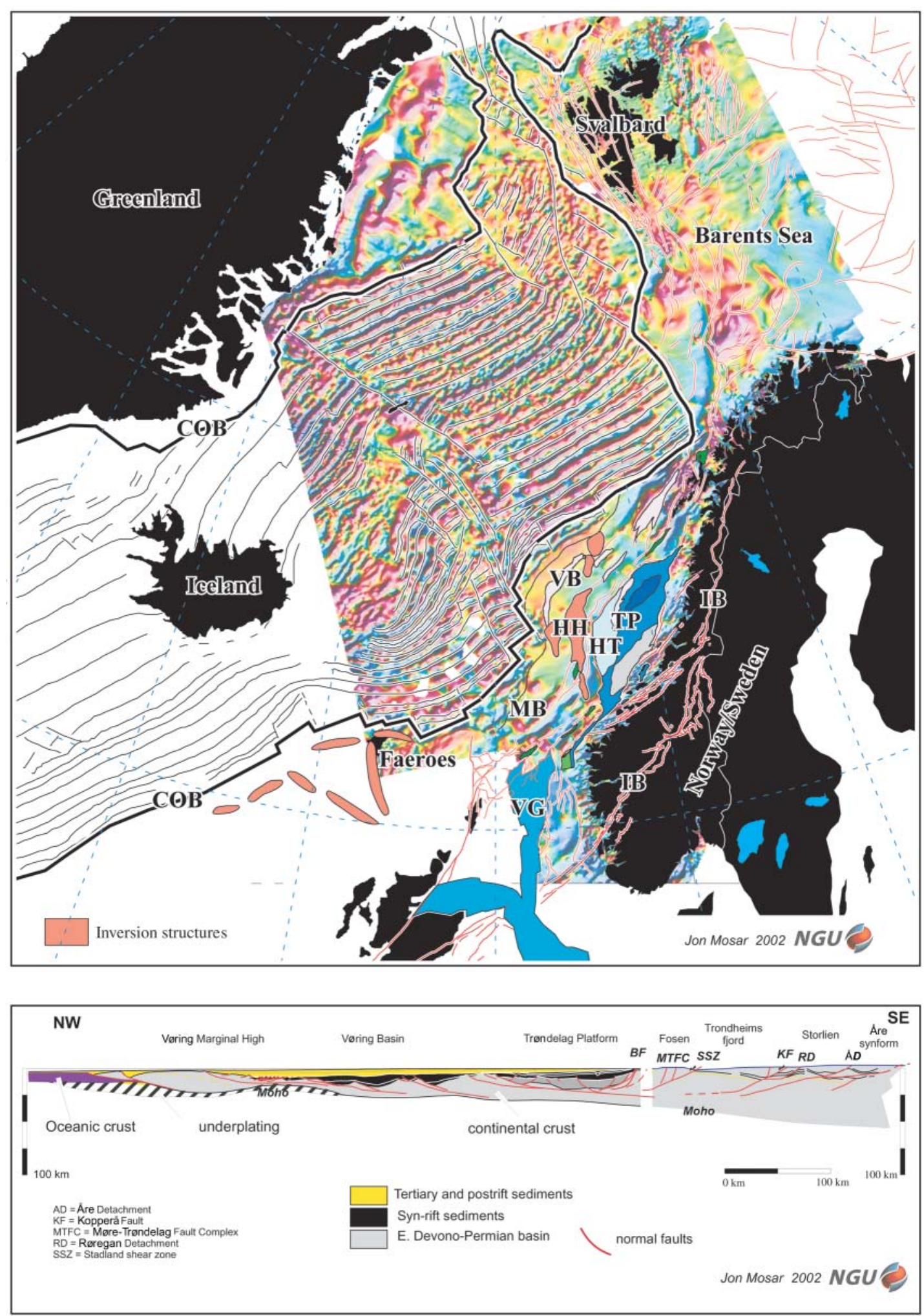

Fig. 1. Magnetic anomaly map of Norway and adjacent ocean areas (based on Olesen et al. 1997; Skogseid et al. 2000) overlain with identified magnetic anomalies (anomalies A5-A24), fracture zones and spreading axes, and a simplified crustal cross-section through Mid-Norway-Trøndelag PlatformVøring Basin. The continent-ocean boundary (COB) is shown as a bold black line. Crustal-scale cross-section through mid-Norway, the Trøndelag Platform and the Vøring Basin into the oceanic crust is after Mosar (2000). The main structural features of the Mid-Norway offshore region are indicated: HH, Helland-Hansen Arch; HT, Halten Terrace; IB, innermost passive margin boundary fault (from Mosar 2000); MB, Møre Basin; TP, Trøndelag Platform; VB, Vøring Basin; VG, Viking Graben. Orange indicates inversion features. Additional geographical details are shown in Fig. 2. Faults and basins in the offshore Norway region and in the Barents Sea are after Blystad et al. (1995) and from the NPD database (unpublished). In the cross-section the IB is coincident with the Åre detachment. 
which lies the transition zone to oceanic crust and the true continent-ocean boundary (COB). The marginal highs are characterized by substantial amounts of intrusive rocks, as well as thick layers of seaward-dipping reflectors resulting from extrusive volcanic rocks (Eldholm et al. 1988, 1989, 2000; Berndt et al. 2001). Volcanism has been linked to the initial break-up of the NE Atlantic and is associated with important crustal thinning and magmatic underplating (van Wijk et al. 2001).

The rift-drift transition occurred in Early Eocene time just before anomaly 24B. A post-break-up period of inversion resulted in the formation of a series of compressional structures. Although only crudely dated, two major periods of inversion can be discriminated: one in Late Eocene-Early Oligocene time and one in Miocene time (Doré \& Lundin 1996; Vågnes et al. 1998; Lundin \& Doré 2001). These features are predominantly located within the Vøring Basin, e.g. the Naglfar Dome, Vema Dome, Modgunn Arch and the Helland-Hansen Arch (Bukovics et al. 1984; Blystad et al. 1995; Ziegler et al. 1995; Vågnes et al. 1998; Sanchez-Ferrer et al. 1999; Lundin \& Doré 2001) and within the Faeroe-Shetland Basin (Boldreel \& Andersen 1993; Ziegler et al. 1995; Doré \& Lundin 1996; Doré et al. 1999). Because of their potential for oil exploration, the existing data on these structures are largely confidential and relatively little information has been published, and no regional comparative study is available to date. The Helland-Hansen Arch (formerly referred to as the Molde High) is one of the largest domal features (Hinz et al. 1982; Hamar \& Hjelle 1984; Bukovics \& Ziegler, 1985; Grunnaleite \& Gabrielsen 1995; Ziegler et al. 1995; Doré \& Lundin 1996; Swiecicki et al. 1998; SanchezFerrer et al. 1999; Brekke 2000; Lundin \& Doré 2001). The Møre Basin appears to be relatively shielded from the effects of inversion, with the exception of the Ormen Lange Dome (southern extension of the Helland-Hansen Dome; NE Møre Basin; Fig. 1) at the transition between the Møre and the Vøring Basins. Despite being important for future hydrocarbon exploration in the Norwegian Sea, these inversion structures represent a total crustal shortening of less than $1 \%$. Similar structures are known further south in the Faeroe-Shetland Basin (Boldreel \& Andersen 1993, 1998; Ziegler et al. 1995; see also discussion by Doré \& Lundin 1996).

Many different models have been proposed to explain the formation of the Tertiary inversion structures, but a single mechanism fails to fully explain the variability in structural style, timing, amplitude and their growth history. The aim here is to discuss the importance of the differential sea-floor spreading rates in the evolution of the structures along the Mid-Norway continental margin, rather than to present a detailed structural analysis of the inverted domes. Via a new analysis of the ocean spreading velocities in the three domains described above, we reassess previously published models. The preferred alternative model we present draws on the differences in oceanic lithosphere generation in the different parts of the Greenland Sea and the Norwegian Sea as a mechanism to initiate inversion along the passive margin, and also to explain the presence or absence of inversion structures.

\section{Plate tectonic models and half-spreading velocities}

As a background for our study we use plate tectonic reconstructions based on newly determined rotation parameters for the opening of the North Atlantic (Torsvik et al. 2001b); this model incorporates Tertiary Euler poles calculated from best-fit magnetic anomalies from the Norway, Greenland and Lofoten Basins
(Fig. 2). The reconstructions demonstrate that the bulk of extension on the Norwegian-Greenland Sea passive margin was accomplished during Cretaceous time, before the rift-drift transition in Early Eocene time (Fig. 3), which is consistent with structural modelling (e.g. Walker et al. 1997). An important change in sea-floor spreading occurred with the abandoning of the Ægir Ridge system, and the northward propagation of the Reykjanes Ridge into areas west of the Jan Mayen microcontinent between anomaly 7 and 13 time (25-33.3 Ma; Figs. 2 and 3; Vogt 1986a; Müller et al. 2001). Abandonment of the Ægir Ridge is coincident with a major reorganization of plate boundaries in the Arctic-North Atlantic domain, including termination of sea-floor spreading in the Labrador Sea-Baffin Bay (before anomaly 13; Srivastava \& Tapscott 1986). Greenland joined the North American plate and Jan Mayen the European plate (Ziegler 1988). This ridge jump is also coincident with a change in both absolute and relative plate motion in Oligocene time at c. $30 \mathrm{Ma}$ (Torsvik et al. 2001a, and Fig. 2).

To evaluate if the change in plate motion is coincident with changes in rate of sea-floor spreading, new half-spreading rates have been calculated (Table 1). This was achieved by measuring the distance between dated magnetic anomalies and dividing by the anomaly time difference to estimate spreading rates in centimetres per year. This involved a review of different interpretations of anomaly patterns in the North Atlantic and a review of the age dating of the anomalies to construct a consistent base model (Figs. 1 and 2, Table 1; see also Torsvik et al. 2001a, 2001b). Distances were measured along tectonic flowlines, which parallel major transforms and fracture zones and thus represent the opening direction. Five flow-lines were selected (Fig. 2) associated with the Mohns Ridge (Greenland Sea, FL1, 11-14), six lines across the now extinct Ægir Ridge (Norwegian Sea, FL2-4, 8-10), four lines associated with the younger Kolbeinsey Ridge (FL6, 6g, 7, 7g), and finally one line on the flank of the Reykjanes Ridge (FL5) for comparison with our Norwegian-Greenland Sea analysis (Figs. 2 and 4). Distances along flow-lines were calculated interactively with the GMAP software system (Torsvik \& Smethurst 1999), and we consider that spreading rate calculations have errors of less than $10 \%$. Results are discussed according to the various structural domains (Table 1 and Fig. 4). Similar studies have already been carried out (Vogt 1986a), but the relative magnitude of spreading velocities between oceanic domains has not yet been adequately addressed in the literature.

\section{Mohns Ridge (FL1, FL11-14)}

Spreading rates along the Mohns Ridge were estimated at $0.78 \mathrm{~cm} \mathrm{a}^{-1}$ for the last $10.3 \mathrm{Ma}$, which matches well the $0.77 \mathrm{~cm} \mathrm{a}^{-1}$ estimate of Vogt (1986a). All analyses show a similar time-trend independent of oceanic domain, i.e. the initial opening of the North Atlantic was associated with high spreading rates, which decreased systematically toward anomaly 13 and 7 times, and increased sharply from anomaly 7 , reaching a plateau before the present day.

The initial and high opening velocity along FL1 is $1.8 \mathrm{~cm} \mathrm{a}^{-1}$. A lower spreading velocity than along FL1 is noticed in the SE corner of this domain, close to the Jan Mayen Transform and the Vøring Marginal High, with values as low as $0.8 \mathrm{~cm} \mathrm{a}^{-1}$ along FL12. This low value is probably related to the uncertainty in determining magnetic anomaly 24 in this area (the original dataset indicates two sets of anomalies $24 \mathrm{a}$ and $24 \mathrm{~b}$, possibly resulting from a ridge jump briefly after opening of the ocean). After lowering of the spreading velocities between anomalies 13 


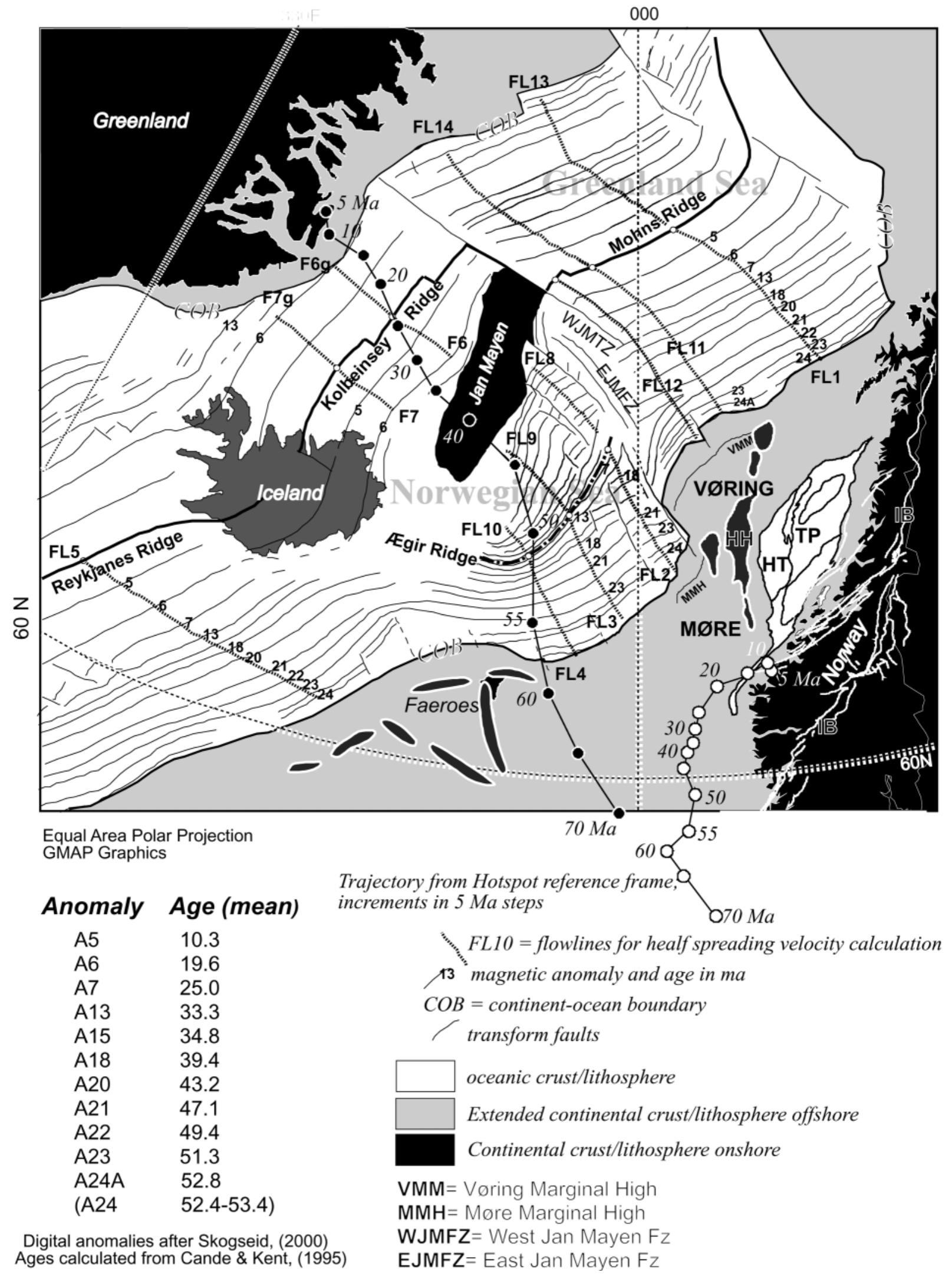


and 7 , velocity recovery is recognized after anomaly 7 with fairly constant rates for the last $20 \mathrm{Ma}$.

\section{Agir Ridge (FL1-4, FL8-10)}

As for the Greenland Sea, spreading rates along the Ægir Ridge were high during the initial opening phase of the North Atlantic (Fig. 4), with peak spreading rates exceeding $2 \mathrm{~cm} \mathrm{a}^{-1}$. For all flow-lines a more or less systematic decrease in spreading rates is noticed toward anomaly $13(33.3 \mathrm{Ma})$, but from NE to SW we also notice a systematic decrease in spreading rates along the Ægir Ridge. Opening of the Ægir Ridge system involved an important rotational component of its western margin. Before extinction of the Ægir Ridge and the initiation of sea-floor spreading along the Kolbeinsey Ridge (see Figs. 2 and 3), spreading rates along the former decreased to $0.38,0.21$ and $0.14 \mathrm{~cm} \mathrm{a}^{-1}$ at FL2, FL3 and FL4, respectively. These are all lower than contemporaneous spreading rates observed along the Mohns Ridge to the north. Moreover, in the time interval of anomalies 18-7, the rate of accretion of new sea floor along the Ægir Ridge was higher along the SE flank than along the NW one, as evidenced by data along FL3 and FL9 (Fig. 4).

\section{Kolbeinsey Ridge (FL6, 7, FL6g, 7g)}

With the extinction of the Ægir Ridge, sea-floor spreading commenced between the Jan Mayen microcontinent and East Greenland, leading to the development of the Kolbeinsey Ridge system. Half-spreading rates along this ridge vary between 0.77 and $1.05 \mathrm{~cm} \mathrm{a}^{-1}$ and were marginally higher in the western domain than in the eastern domain.

\section{Reykjanes Ridge (Fl5)}

For comparison with the Greenland and Norwegian Seas, a flowline from the southeastern flank of the Reykjanes Ridge was analysed. The overall picture is similar to that for the Greenland Sea. Initially high spreading rates were followed by a velocity minimum between anomalies 13 and 7 , and subsequently increased again to average $1.06 \mathrm{~cm} \mathrm{a}^{-1}$ for the last $10.3 \mathrm{Ma}$. This is identical to the calculation of $\operatorname{Vogt}(1986 \mathrm{a}, 1986 \mathrm{~b})$.

\section{Comparison of spreading rates between oceanic domains}

From the above analysis it is clear that changes occurred not only in the rate of sea-floor spreading along the flanks of the Arctic-North Atlantic Ocean, but that the evolution of their ridge systems also shows major differences through time. Current spreading rates along the Mohns and Reykjanes Ridges can vary by as much as $35 \%$.

During the last $10 \mathrm{Ma}$, average half-spreading rates decrease from $1 \mathrm{~cm} \mathrm{a}^{-1}$ along the Reykjanes Ridge to $0.91 \mathrm{~cm} \mathrm{a}^{-1}$ along the Kolbeinsey Ridge and to $0.8 \mathrm{~cm} \mathrm{a}^{-1}$ along the Mohns Ridge.
The Kolbeinsey and Mohns Ridge systems are considered to be very slow-spreading ridges $\left(<1 \mathrm{~cm} \mathrm{a}^{-1}\right.$; Géli 1993; Géli et al. 1994). The values are on average $0.81 \mathrm{~cm} \mathrm{a}^{-1}$ for the Greenland Sea over the last $10 \mathrm{Ma}$ (FL1, 11-14; Table 1) which compares well with estimates of $0.7-0.8 \mathrm{~cm} \mathrm{a}^{-1}$ by Géli et al. (1994).

Initial spreading rates were highest in the Reykjanes Ridge, and lowest in the Mohns Ridge, the Ægir Ridge being intermediate. However, the situation changed between anomalies 22 and 23, and the rate for the Mohns Ridge was then greater than that for the Ægir Ridge. Overall, there is a continuous decrease in spreading velocity until anomaly 13 (Fig. 4).

Along the Ægir Ridge we notice that systematically lower spreading rates occurred from NE to SW, which approached values as low as $0.14 \mathrm{~cm} \mathrm{a}^{-1}$ before its extinction. The differences in spreading rates across the Ægir Ridge from east to west demonstrate that more oceanic lithosphere was created east of the Ægir Ridge, resulting in asymmetric spreading. This asymmetry combined with the along-axis NE-SW decrease in oceanfloor production suggests that there is a rotational component to displacement of the Jan Mayen microcontinent. This rotation is further coincident with and probably related to the northward propagation of the Reykjanes Ridge, forming the tip of the incipient Kolbeinsey Ridge and the subsequent detachment of the Jan Mayen microcontinent from Greenland (Figs. 3b and 5). The positioning of the Iceland hotspot near the Greenland edge during this period probably caused additional heating of the lithosphere, which reduced the yield strength of the landward edge of the rifted margin and probably led to a ridge jump into the new zone of weakness (Vink 1984; Müller et al. 2001). This mechanism, combined with the northward rift propagation of the Kolbeinsey Ridge, led to the formation of the Jan Mayen microcontinent.

Relatively high spreading rates are noticed during initial North Atlantic opening (around $2.0 \mathrm{~cm} \mathrm{a}^{-1}$ ). A systematic decrease occurs toward anomalies 13 and 7, with some recovery for the last $20 \mathrm{Ma}$ (Fig. 4). This decrease in velocity is also noticed in absolute velocities for the North Atlantic as obtained from the hotspot reference frame (Torsvik et al. 2001b). The velocity recovery at c. $20 \mathrm{Ma}$ coincides with the positioning of the Iceland plume beneath the North Atlantic spreading ridge, which may have increased upwelling below the ridge, increased ridge push and caused a NE shift in the absolute motion direction of Eurasia (Fig. 2; Torsvik et al. 2001a). At the same time, the Ægir Ridge became extinct and a ridge jump towards the Kolbeinsey Ridge occurred. The cessation of the Ægir Ridge system is coincident with cessation of spreading in the Labrador Sea leading Greenland to join the North American plate, and thus causing a major change in plate dynamics. Favoured by the positioning of the hotspot (Müller et al. 2001), first under East Greenland, and then under the mid-ocean ridge, the Jan Mayen microcontinent separated from Greenland and the Kolbeinsey Ridge propagated towards the JMTZ (Fig. 3). Furthermore, following anomaly 7 , we see the final separation of Greenland and Svalbard and the development of the Knipovitch Ridge

Fig. 2. Simplified map with magnetic anomalies (as in Fig. 1) and fracture zones. Inversion structures along the European passive margin are shown in black; the Trøndelag Platform and its internal basins are shown in white; major faults are shown only for the Mid-Norway margin and the Barents SeaSvalbard area, and the most important normal faults onshore Norway are also shown, including the innermost boundary fault of the passive margin (IB; Mosar 2000). Both the European and the Greenland margins are volcanic passive margins (Skogseid et al. 2000). Flow-lines used to calculate sea-floor half-spreading rates are shown as stippled lines. Anomaly numbers are indicated (5, 6, 7, 13, 18 and 20-24). Also shown is the 'absolute' movement of two geographical locations, one in Greenland $\left(\bullet ; 71.5^{\circ} \mathrm{N}, 338^{\circ} \mathrm{E}\right)$ and one on the Mid-Norway margin $\left(\circ ; 62.5^{\circ} \mathrm{N} ; 6^{\circ} \mathrm{E}\right)$, as obtained from the fixed hotspot reference frame (Müller et al. 1993; Torsvik et al. 2001b). A discussion on the use of hotspots as fixed markers and a reference frame for plate tectonics is beyond the scope of this paper, but studies on the Iceland hotspot (Torsvik et al. 2001a, 2001b) show that there is reasonable overlap between hotspot and palaeomagnetic reconstructions for the North Atlantic, and that therefore the assumption of a fixed Iceland hotspot is valid. 

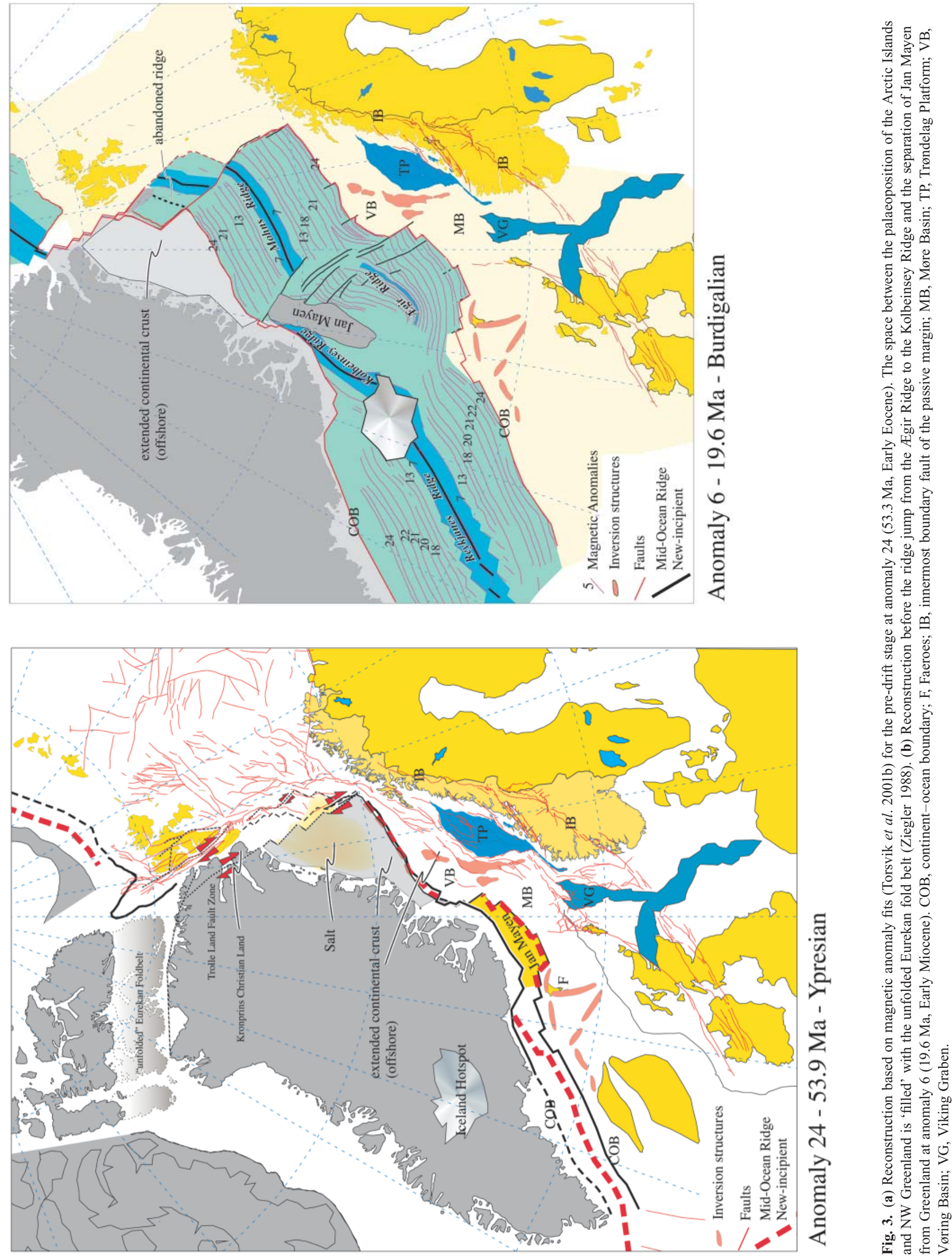

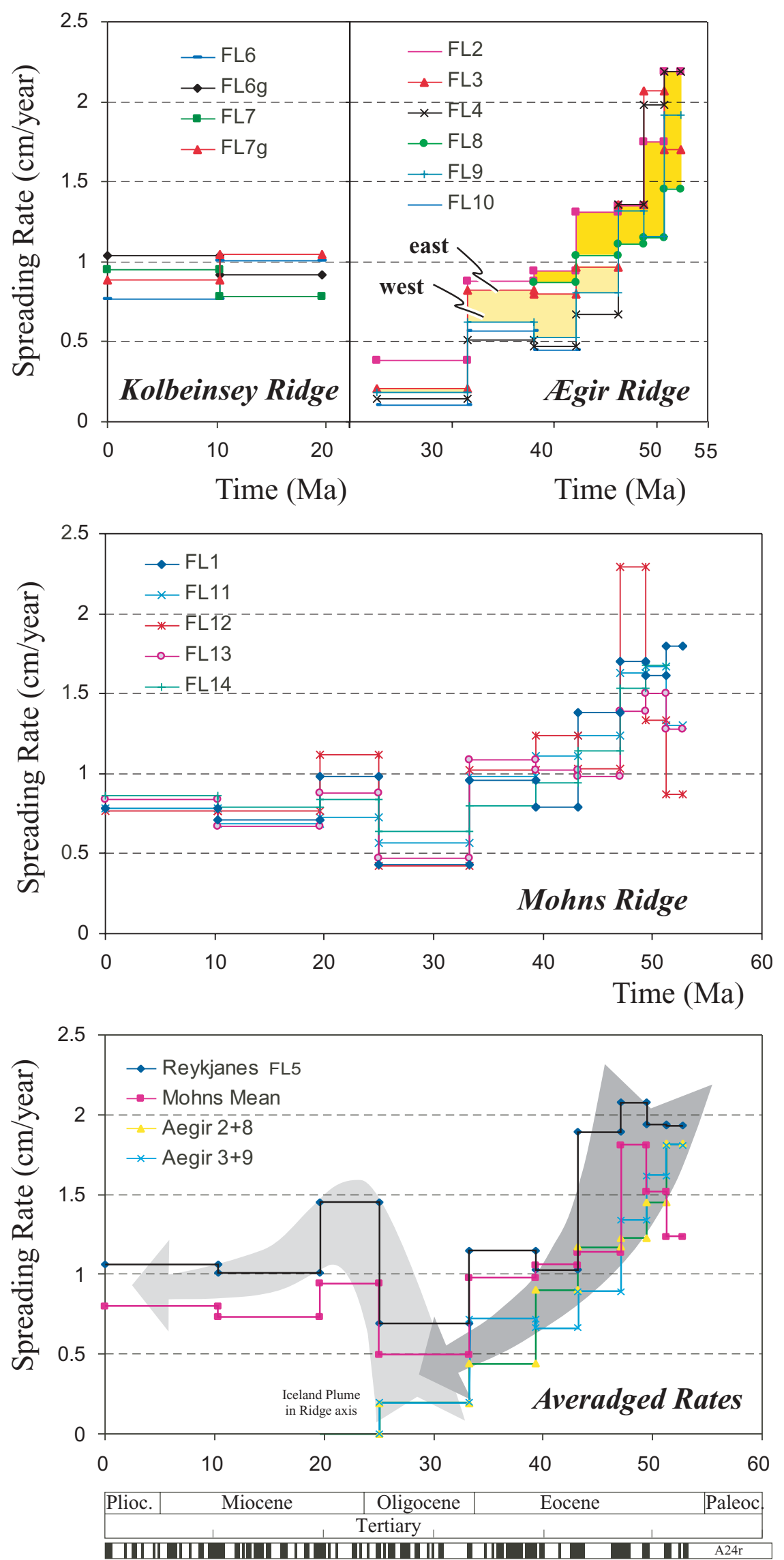

(Seafloor spreading at or prior to A24 (A24R=53.3-55.9 Ma)
Fig. 4. Calculation of half-spreading rates v. time along lines based on tectonic flowlines (see Fig. 2) for the various ridge systems. 
Table 1. Spreading rates ( $\mathrm{cm} \mathrm{a}^{-1}$ ) along flow-lines for various sections of the ridge systems studied (locations are shown in Fig. 2)

\begin{tabular}{|c|c|c|c|c|c|c|c|c|c|c|}
\hline Anomaly: & $0-\mathrm{A} 5$ & A5-6 & A6-7 & A7-13 & A13-18 & A18-20 & A20-21 & A21-22 & A22-23 & A23-24A \\
\hline From: & 0 & 10.3 & 19.6 & 25.0 & 33.3 & 39.3 & 43.2 & 47.1 & 49.4 & 51.3 \\
\hline To: & 10.3 & 19.6 & 25.0 & 33.3 & 39.3 & 43.2 & 47.1 & 49.4 & 51.3 & 52.8 \\
\hline Difference: & 10.3 & 9.3 & 5.4 & 8.3 & 6.0 & 3.9 & 3.9 & 2.3 & 1.9 & 1.5 \\
\hline \multicolumn{11}{|c|}{ Mohns Ridge SE } \\
\hline FL1 & 0.78 & 0.71 & 0.98 & 0.43 & 0.96 & 0.79 & 1.38 & 1.70 & 1.61 & 1.80 \\
\hline FL11 & 0.78 & 0.69 & 0.73 & 0.57 & 0.98 & 1.11 & 1.24 & 1.63 & 1.67 & $1.30 ?$ \\
\hline FL12 & 0.77 & 0.77 & 1.12 & 0.42 & 1.02 & 1.24 & 1.03 & 2.29 & 1.33 & 0.87 \\
\hline FL14 & 0.86 & 0.79 & 0.84 & 0.64 & 0.80 & 0.94 & 1.14 & 1.53 & 1.68 & \\
\hline \multicolumn{11}{|c|}{ Ægir Ridge SE } \\
\hline FL2 & Extinct & Extinct & & 0.38 & 0.88 & 0.94 & 1.31 & 1.35 & 1.75 & 2.19 \\
\hline FL3 & Extinct & Extinct & & 0.21 & 0.82 & 0.80 & 0.97 & 1.36 & 2.07 & 1.70 \\
\hline \multirow{2}{*}{\multicolumn{11}{|c|}{ Ægir Ridge $N W$}} \\
\hline & & & & & & & & & & \\
\hline FL8 & Extinct & Extinct & & - & - & 0.87 & 1.04 & 1.11 & 1.15 & 1.45 \\
\hline \multicolumn{11}{|c|}{ Kolbeinsey Ridge SE } \\
\hline FL6 & 0.77 & 1.01 & & & & & & & & \\
\hline FL7 & 0.95 & 0.78 & & & & & & & & \\
\hline \multicolumn{11}{|c|}{ Kolbeinsey Ridge $N W$} \\
\hline FL6g & 1.04 & 0.92 & & & & & & & & \\
\hline FL7g & 0.89 & 1.05 & & & & & & & & \\
\hline
\end{tabular}

ocean floor linking the North Atlantic to the Arctic Ocean (Fig. 3).

The analyses of spreading rates, the amount of oceanic lithosphere production, and the orientation of forces associated with the formation of ocean floor are relevant to understand the stresses exerted, especially by ridge push, on the passive margin. Stresses within lithospheric plates reflect extension and compression as a result of body forces and surface tractions linked to thermally induced gravitational instabilities (Engelder 1993). It is the topographic and density variation between ridge and subsided cold margin that generates compressional stresses directed towards the plate interior and generally perpendicular to the ridge (Bott 1992; Zoback 1992). Along divergent margins, the forces are directed away from the plate interior and along transform zones the forces are tangential to the boundary (Forsyth \& Uyeda 1975; Wdowinski 1998). It appears that the plate-wide stress field is generated by the gravitational forces at mid-ocean ridges (Engelder 1993). The increase in oceanic lithospheric thickness and depth of the ocean floor is a function of time and heat flow, and is similar for all oceans (Stein \& Stein 1992; Carlson \& Johnson 1994; Doin \& Fleitout 1996). The increase in lithospheric thickness as a result of cooling and the related ridge push are independent of spreading velocities (Dahlen 1981; Turcotte \& Schubert 1982). The differential production of oceanic lithosphere as a result of changes in spreading velocity should thus not be relevant for the stresses exerted on the passive margin. We therefore propose that the ridge push plays a negligible role in the development of inversion structures. However, oceanic lithosphere cooling models appear to be at odds with the observation that inversion structures along the North Atlantic European passive margin develop in segments characterized by greater oceanic floor production (wider oceans).

\section{Possible mechanisms for the formation of Tertiary inversion structures}

Tertiary inversion structures developed as growth folds from Eocene to Mio-Pliocene time. Each structure (arch or dome) shows a different orientation with respect to the stress-strain field generated from ridge push and follows the trends of the local basin-bounding tectonic features as a result of oblique fault reactivation. Although some features may be related to local space accommodation during extension, most of the larger domes such as the Helland-Hansen Arch (located in the south-central part of the Vøring Basin, Fig. 2) are thought to be due to compressional reactivation of faults that developed during Cretaceous time (Grunnaleite \& Gabrielsen 1995; Vågnes et al. 1998). This is very likely, as many of these domes are underlain by older (probably Jurassic and certainly Cretaceous) faultbounded basins (Sanchez-Ferrer et al. 1999). In the case of the Helland-Hansen Arch, the inversion structure is further mimicking the shape of the edge of the Trøndelag Platform; this strongly suggests a dynamic link to the fault system that shaped this edge and the Cretaceous basin structures west of it. All structures were initiated during the same period, but each structure has subsequently undergone its own development, and although timing is only loosely constrained, there seem to be two major 'pulses' of inversion: in Early Tertiary and Miocene time. This suggests a common causal mechanism and the interaction of subprocesses to allow for local variation. Several possibilities have been suggested in the literature, in a general manner (Zoback 1992; Engelder 1993; Ziegler et al. 1995), and more specifically applied to the Norwegian passive margin, as follows.

Alpine stress field. To explain the formation of Tertiary inversions, several workers have discussed the possibility of transmit- 
ting stress resulting from the Alpine Orogeny and transmitted through the European plate (Boldreel \& Andersen 1993, 1998; Vågnes et al. 1998). Although this idea has successfully been applied to features observed in the North Sea realm (e.g. Ziegler 1989; Ziegler et al. 1998), we strongly argue that this hypothesis should be applied with caution to the Mid-Norway shelf (see also discussion by Gölke \& Coblentz 1996; Gölke et al. 1996; Pascal \& Gabrielsen 2001). Indeed, the Norwegian North Atlantic passive margin lies on the Fennoscandian Shield, which forms part of the East European Craton that is bounded to the SW by the Sorgenfrei-Tornquist Zone and the Teisseyre-Tornquist Zone (Pharaoh 1999). This major lithospheric boundary separates the North Sea area and the Central European terrane collage from the stable East European-Scandinavian craton. Far-field stresses transmitted from the Alpine Orogeny may be strongly deflected across this lithospheric boundary and may not act significantly on the Norwegian North Atlantic passive margin, which formed at the NW edge of the East European-Scandinavian craton.

Rifting and subaerial sea-floor spreading. During the Early Tertiary rifting phases and the associated faulting and rift-flank uplift, a phase of subaerial sea-floor spreading may have added an extra topographic momentum, and is considered to have aided initiation of inversion along pre-existing Cretaceous faults (Vågnes et al. 1998).

Underplating and Iceland hotspot influence. The emplacement of a plume head beneath the lithosphere will result in increased uplift (Bott 1991). Modelling of the extension of the plume head under the Greenland margin and along the developing North Atlantic spreading ridge (Skogseid et al. 2000) shows a close spatial relation between subaerially emplaced basalts and modelled uplift. Similarly, underplating can create extra uplift of between 0.8 and $1.5 \mathrm{~km}$ according to Skogseid et al. (2000). These combined effects may have created an initial topographic gradient that may have triggered the formation of inversion structures. However, new thermomechanical models of rift margins show that no hotspot influence is required to explain the large volumes of melt generated during the rift-drift transition period (Anderson 2000; van Wijk et al. 2001). Broad-scale thermal doming as a result of underplating creates regional deviatoric stress that can interfere with shear-traction forces exerted at the base of the lithosphere (see discussion below; Bott 1991; Ziegler et al. 2001).

Ridge push and mantle drag. At present, broadly NW to NNW compression over large portions of the European continent suggest that intra-plate stress in the North Atlantic region is related to ridge push, which corresponds to an average force from all ridge segments roughly perpendicular to the nearest ridge (Zoback 1992; Gölke \& Coblentz 1996). It is these forces that have been invoked to explain the formation, or at least the initiation, of inversion and development of domes (Boldreel \& Andersen 1993; Ziegler et al. 1995; Doré \& Lundin 1996; Boldreel \& Andersen 1998; Vågnes et al. 1998; Pascal \& Gabrielsen 2001). The increase in water depth and in lithospheric thickness is most important in the first 20-30 Ma of ocean-floor production (Stein \& Stein 1992; Carlson \& Johnson 1994; Doin \& Fleitout 1996), and after some $20 \mathrm{Ma}$ the oceanic lithosphere becomes negatively buoyant (Cloos 1993). However, the ridgepush mechanism dominates the stable interior of lithospheric plates only after the newly formed oceanic lithosphere has cooled and contracted for more that $30 \mathrm{Ma}$ (Engelder 1993). Furthermore, recent studies on ridge push (Fejerskov \& Lindholm 2000) indicate that this force alone is not sufficient to bring about basin inversion as seen in the Tertiary dome development of the Vøring Basin. Modelling of plate-driving mechanisms has shown that from topography and ridge push are not sufficient to drive plate motion, and that an important role is played by mantle flow exerting shear-traction forces at the base of the lithosphere (mantle drag; Bott 1991, 1992; Wilson 1993; Ziegler 1993; Bird 1998; Ziegler et al. 2001). In addition, broad-scale thermal doming or the influence from a hotspot can cause additional mantle drag that may combine in a constructive or destructive way with existing drag (Bott 1991; Bird 1998; Ziegler et al. 2001). Also, as ridge push is time related, a similar effect would be expected both in the Vøring and Møre Basins. However, the Møre Basin does not show inversion structures, despite a basin development history similar to that of the Vøring Basin.

Asymmetric spreading and mantle drag. The amount of oceanic lithosphere generated at the Mohns and Reykjanes Ridge systems was higher during the period between anomalies 21 and 13 than in the Ægir system. Furthermore, in the Ægir Ridge system there is asymmetric spreading, which points to an asymmetric flow pattern in the asthenosphere. This asymmetric spreading has been linked to the formation of the Jan Mayen microcontinent and to ridge jump (Müller et al. 2001). Across the ridge, the asymmetric flow pattern in the asthenosphere will cause differential drag (mantle drag; Forsyth \& Uyeda 1975) at the base of the lithosphere (Stein et al. 1977). The viscous coupling between asthenosphere and lithosphere may act as a driving, or as a resisting, force to plate motion. The model of Stein et al. (1977) predicts that in asymmetric spreading the trailing flank is spreading fastest; those workers also argued that the shear under the accreting plate is lowest. By applying this model to the Ægir system, where more ocean floor is created east of the ridge (the trailing flank), we would expect less stress developing from mantle drag on the Norway passive-margin side. We can also expect a lower drag than in a symmetric system such as the Mohns Ridge. Thus, we suggest that forces exerted by this differential drag along the passive margin are also different and may explain the location of inversion structures in the Faeroe area and in the Vøring Basin, whereas the Møre Basins has no such structures.

Differential sediment loading. It has been suggested by Stuevold et al. (1992) that intra-basinal arching is an effect of Neogene sediment loading, enhancing an existing basin configuration and reactivating Late Cretaceous-Paleogene faults. According to those workers 'the Helland-Hansen Arch is a result of differential subsidence, most pronounced during Eocene and Oligocene time, and increased Neogene sedimentation, which induced instability as a result of differential loading of dense terrigeneous material on thick Cretaceous clays'. The higher sediment input is a result of renewed continental uplift associated with increased erosion. The increased sediment input and uplift cause bending of the crust, which generates flexural stresses with a compressional component in the upper crust underneath the sediment basin (Fejerskov \& Lindholm 2000). The highest stresses are expected in basins with high sedimentation rate and thin lithosphere (Stein et al. 1989). Given the high sedimentation rate and the earthquake activity (both compressional and tensional focal mechanisms; Fjeldskaar et al. 2000; Lindholm et al. 2000) on the Norway margin, this mechanism possibly plays a significant role.

Shear: Jan Mayen Transform Zone (JMTZ) and Jan Mayen lineament. The proximity of the Helland-Hansen Arch, one of the most prominent Tertiary domes (Sanchez-Ferrer et al. 1999), 


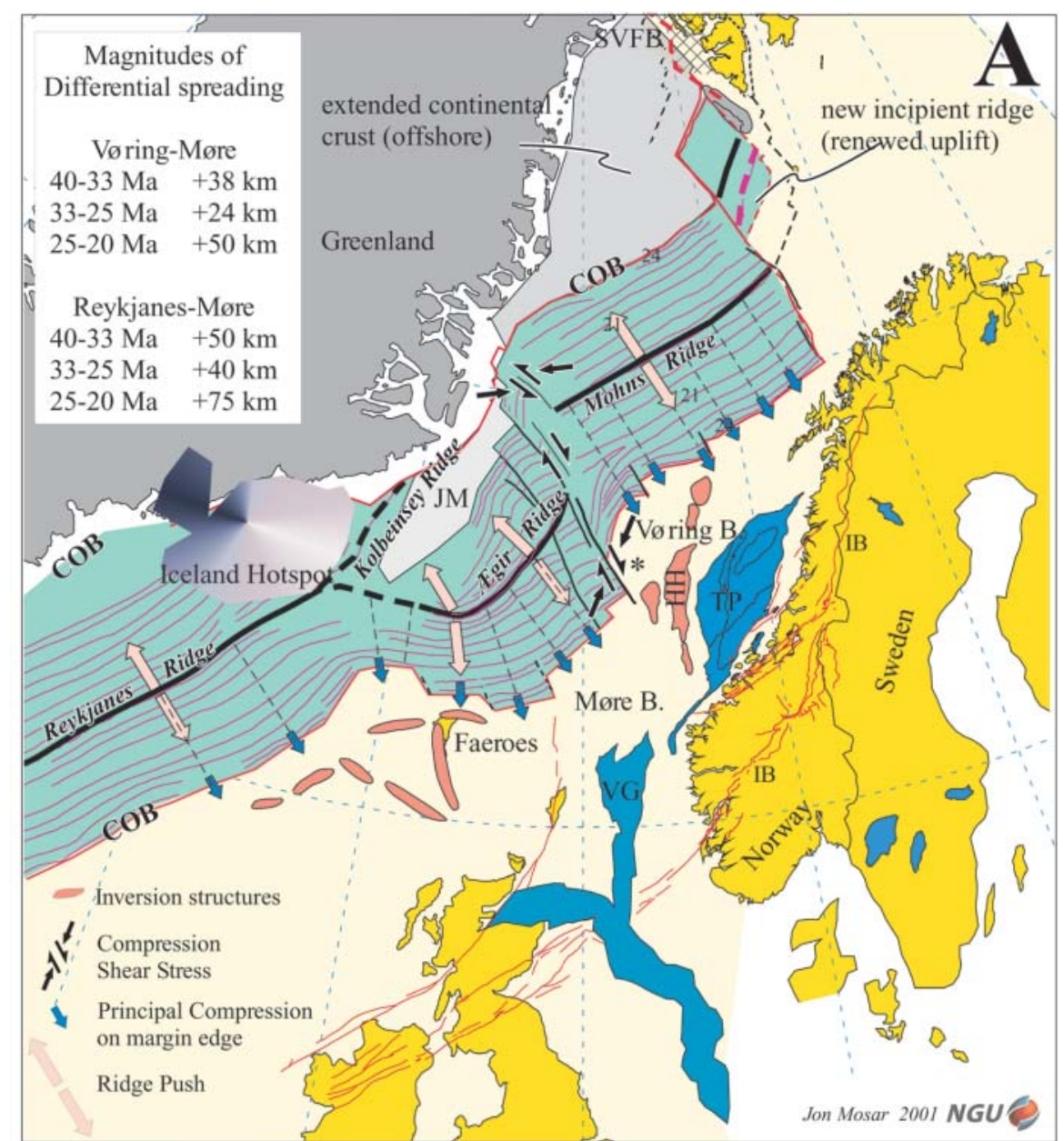

\section{Anomaly 13 - 33.3 Ma Rupelian}
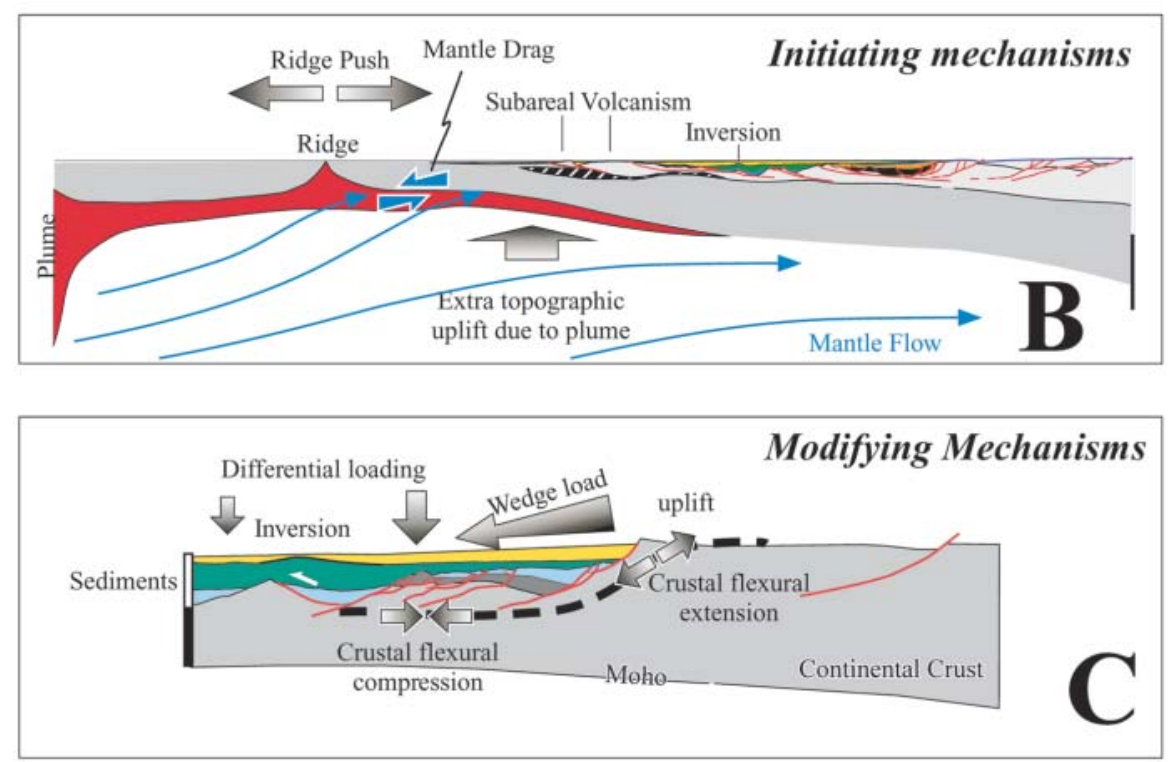

Fig. 5. Interpretation of spreading velocity and deduced shear sense along the major transform faults. (a) Early Oligocene plate reconstruction (anomaly 13). The differences in magnitudes of ocean-floor production between the Reykjanes Ridge, Ægir Ridge (Reykjanes-Møre) and Mohns (Vøring-Møre) Ridge are indicated for the periods 40-33, 33-25 and 25-20 Ma. Estimated present-day direction of ridge push and inversion features along the European passive margin of the North Atlantic are shown (inversion features from Blystad et al. 1995; Doré \& Lundin 1996). In the vicinity of the Jan Mayen Transform and the Vøring outer margin $(*)$ the combined effect of ridge push and shear induced along the transform zone causes the stress trajectory to deviate from a margin-perpendicular position to a more north-south-oriented direction. $\mathrm{COB}$, continent-ocean boundary; HH, HellandHansen Arch; IB, innermost boundary fault of the passive margin; JM, Jan Mayen microcontinent; TP, Trøndelag Platform; SVFB, Svalbard fault boundary; VG, Viking Graben. (b) Simplified sketch of the initiating mechanisms that help induce the formation of inversion structures in the extended continental crust. (c) Sketch of the possible modifying mechanisms that sustain continued growth of the inversion structures. and the JMTZ has led to much speculation on the influence of the JMTZ and its projection into the continental margin, and by inference from other transform zones, on the development of these domes (Ziegler et al. 1995; Doré \& Lundin 1996; Lundin \&
Doré 2001). The JMTZ separates the extinct Ægir Ridge oceanic domain from the Mohns Ridge oceanic domain, and is formed by several fracture zones. By definition, the JMFZ is a purely oceanic feature. The continuation of the JMTZ into the extended 
continental crust of the passive margin, often referred to as the Jan Mayen lineament, should be considered as a soft link between the Møre Basin and the Vøring Basin-Trøndelag Platform. Across the JMTZ a left-lateral ridge offset between the Ægir Ridge and the Mohns Ridge occurs. This ridge offset is an original feature and is due to the geometry of the final break-up line (Figs. 2, 3 and 5). The location of the JMTZ at the junction between the Møre Basin and the Vøring Basin may be due to inherited pre-break-up structures. To the west of Jan Mayen the JMTZ also offsets the Reykjanes and Mohns Ridges (Fig. 2).

From the analyses of the spreading rates it appears that from anomaly 24 to the present the Mohns Ridge system is spreading faster (developing more oceanic crust-lithosphere) than the Ægir Ridge system. Given the evolution of the Mohns Ridge system compared with the Ægir Ridge system and that the ridge system is left-laterally offset across the JMTZ, the motion across the JMTZ between the two ridge segments must be right-lateral (Fig. 5). If the JMTZ extends or projects into the continental crust (Jan Mayen lineament) as suggested by Ziegler et al. (1995), Doré \& Lundin (1996) and Lundin \& Doré (2001), the compression axes are not favourably oriented to suggest a possible link to the development of the Tertiary inversion features in the Vøring Basin, especially the Helland-Hansen Arch. This is in contradiction to a model of left-lateral motion along the Jan Mayen lineament as proposed by Doré \& Lundin (1996). Those workers proposed that the Jan Mayen lineament extends as a transfer-shear zone into the continental crust of the passive margin and is responsible for the development of the inversion features. On the basis of our own analyses, this concept does not appear to be viable.

Passive margin geometry and compressional strength. Not yet included in models presented to date is the structure and the geometry of the passive margin and its prime importance in the development of inversion structures. Modelling of the compressional strength of passive margins with an upper plate geometry $\mathrm{v}$. a lower plate geometry (Ziegler et al. 1995) shows that the upper plate margin is weaker than the lower plate margin. Consequently, the upper plate margin is more likely to develop compressional (inversion) structures. On the basis of commercial, confidential deep seismic and present investigations at NGU (Geological Survey of Norway), it can indeed be shown that (1) Norway's North Atlantic passive margin developed as an asymmetric passive margin, and (2) the asymmetry of the passive margin in the Møre Basins is of lower plate geometry, whereas in the central Vøring Basin-Trøndelag Platform domain it is of upper plate geometry (Fig. 1; Mosar 2000; Mosar et al. 2001a, 2001b). In the Vøring Basin, major normal faults dip to the east (Fig. 1), whereas in the Møre Basin they dip to the west (Brekke 2000). We thus have a shift from upper plate to lower plate geometry between the Vøring and the Møre Basins. Furthermore, the Faeroe-Shetland area to the south of the Møre Basin and to the NW of the Shetland Platform is also a potential candidate for an upper plate geometry. Major normal faults are essentially east-dipping, as indicated from shallow and deep seismic profiles (Duindam \& van Hoorn 1987; Gibbs 1987; Grant et al. 1999; Smallwood et al. 2001). We therefore propose here that the upper v. lower plate geometry is a key factor in the development of the inversion structures, and because of its lower plate geometry the Møre Basin has not been able to sustain the development of inversion structures.

\section{Discussion and conclusion}

Although many models have been advanced for the development of inversion structures along the Norwegian Atlantic passive margin, we favour an explanation based on the differences in sea-floor spreading rates and the accretion of oceanic lithosphere. Rather than involving ridge-push forces, we propose that mantledrag forces are responsible for initiating the development of Tertiary inversion structures adjacent to the various oceanic domains flanking the Mid-Norway passive margin. Furthermore, these forces act upon margins with different geometries: upper plate geometry in the Vøring Basin-Trøndelag Platform portion and possibly also in the Faeroe-Shetland domain, and lower plate geometry in the Møre Basin portion of the European North Atlantic passive margin. Given the mechanical constraints, it has been shown that upper plate margins, which have a lower compressional strength than lower plate margins, are more prone to develop inversion structures.

It is highly probable that most, if not all, inversion structures involved the reactivation of pre-existing, inherited structures, and that their location was governed by the position and geometry of favourably oriented structures on the passive margin. Such structures probably date back to the Caledonian Orogeny, the transtensional development of Devonian intra-mountain basins, and subsequent extensional tectonics related to the Late Palaeozoic and Mesozoic development of the Norwegian-Greenland Sea rift.

The complex interaction of forces acting successively upon the Norwegian North Atlantic passive margin presumably caused the Tertiary development of inversion structures and domes. Each inversion structure resulted from the combination of two basic mechanisms: (1) an initiating mechanism triggering the inversion movement; (2) a modifying mechanism, which sustained inversion and which may have different causes. The degree to which these mechanisms contributed towards the development of each of the inversion structures differs considerably.

In conclusion, we propose that inversion structures developed in response to reactivated, pre-existing structures. The following mechanisms may have initiated inversion movements.

(1) During the continental break-up phase, plume-related subaerial sea-floor spreading and/or underplating may have enhanced the topographic gradient related to extensional flank uplift.

(2) Initiation of inversion of pre-existing faults and basins was probably caused by a combination of ridge-push and mantle-drag forces. Differential spreading rates and asymmetric sea-floor spreading in the Norwegian Sea are held responsible for the build-up of weaker compressional stresses on the Møre Basin passive margin than on the Vøring and Faeroes margins, where they triggered inversion movements.

(3) We suggest that at the transition from wider oceanic domains (Mohns Ridge and Reykjanes Ridge systems) to narrower oceanic domains (Ægir Ridge system) excess shear stresses along a transform zone may have induced the development of inversion structures on the continental margin near the transfer zone.

Once initiated, the inversion structures keep growing as a result of a combination of several possible modifying mechanisms, as follows.

(1) Amplification of the inversion structures by differential sedimentary loading (developing growth folds) and compaction causes growth of domal structures.

(2) Increased sediment supply from the continent causes the seaward propagation of wedge-shaped sedimentary deposits and differential loading of the shelf. Moreover, renewed uplift of the continent increases this gravity force that acts on the developing inversion structures. Added to this are compressive forces in the upper crust that are related to its flexural bending associated with the increased sediment input. 
Finally, the detailed analysis of spreading velocities is an important technique to assess the various forces or stresses involved in the shaping of passive margins following the breakup. The GMAP software is a sophisticated tool that easily allows genesis of the necessary plate reconstructions and spreading velocity calculations. We suggest that the type of new analysis discussed in this paper has great potential for future studies of other passive margins.

The research presented here is part of the basin analysis and thermochronology project supported by Agip, BPAmoco, Chevron-Texaco, Conoco, ExxonMobil, Norsk-Hydro, Phillips, Shell and Statoil, and carried out at the Geological Survey of Norway (NGU). We thank E. Eide and E. Lundin for many discussions, and G. Stampfli and P. Ziegler for reviews: their suggestions were most beneficial for the paper.

\section{References}

ANDERSON, D.L. 2000. The thermal state of upper mantle; no role for mantle plumes. Geophysical Research Letters, 27, 3623-3626.

Applegate, B. 1997. Models of axial reorganization on a slow-spreading ridge. The structural evolution of the Kolbeinsey Ridge since 10 Ma. Geology, 25, $431-434$.

Berndt, C., Planke, S., Alvestad, E., Tsikalas, F. \& Rasmussen, T. 2001. Seismic volcanostratigraphy of the Norwegian Margin: constraints on tectonomagmatic break-up processes. Journal of the Geological Society, London, 158, 413-426.

BIRD, P. 1998. Testing hypotheses on plate-driving mechanisms with global lithosphere models including topography, thermal structure and faults. Journal of Geophysical Research B, 103, 10115-10129.

Blystad, P., Brekke, H., Færseth, R.B., Larsen, B.T., Skogseid, J. \& Tørudbakken, B. 1995. Structural elements of the Norwegian continental shelf. Part II: the Norwegian Sea region. Norwegian Petroleum Directorate Bulletin, 8, 1-45.

Boldreel, L.O. \& Andersen, S. 1993. Late Paleocene to Miocene compression in the Faeroe-Rockall area. In: PARKer, J.R. (ed.) Petroleum Geology of Northwest Europe: Proceedings of 4th Conference. Geological Society, London, 1025-1034.

Boldreel, L.O. \& ANdersen, S. 1998. Tertiary compressional structures on the Faeroe-Rockall Plateau in relation to northeast Atlantic ridge-push and Alpine foreland stresses. Tectonophysics, 300, 13-28.

Bотт, M.H.P. 1991. Ridge push and associated plate interior stress in normal and hotspot regions. Tectonophysics, 200, 17-32.

Вотт, M.H.P. 1992. Passive margins and their subsidence. Journal of the Geological Society, London, 149, 805-812.

BREKKe, H. 2000. The tectonic evolution of the Norwegian Sea continental margin with emphasis on the Vøring and Møre Basins. In: Nottvedt, A. (ed.) Dynamics of the Norwegian Margin. Geological Society, London, Special Publications, 167, 327-378.

BrekKe, H. \& RiIs, F. 1987. Tectonics and basin evolution of the Norwegian shelf between $62^{\circ} \mathrm{N}$ and $72^{\circ} \mathrm{N}$. Norsk Geologisk Tidsskrift, 67, 295-322.

Brekke, H., Dahlgren, S., Nyland, B. \& Magnus, C. 1999. The prospective of the Vøring and Møre basins on the Norwegian Sea continental margin. In: Fleet, A.J. \& Boldy, S.A.R. (eds) Petroleum Geology of $N W$ Europe: Proceedings of the 5th Conference. Geological Society, London, 1, 261-274.

Brekke, H., Sjulstad, H.I., Magnus, C. \& Williams, R.W. 2001. Sedimentary environments offshore Norway-an overview. In: Martinsen, O.J. \& Dreyer, T. (eds) Sedimentary Environments Offshore Norway-Palaeozoic to Recent. Elsevier, Amsterdam, 10, 7-37.

Bukovics, C. \& Ziegler, P.A. 1985. Tectonic development of the Mid-Norway continental margin. Marine and Petroleum Geology, 2, 12-22.

Bukovics, C., Cartier, E.G., Shaw, P.A. \& Ziegler, P.A. 1984. Structure and development of the mid-Norway continental margin. In: SociETy, N.P. (ed.) Petroleum Geology of the North European Margin. Graham \& Trotman, London, 407-423.

Carlson, R.L. \& Johnson, H.P. 1994. On modeling the thermal evolution of the oceanic upper mantle: an assessment of the cooling plate model. Journal of Geophysical Research B, 99, 3201-3214.

CLoos, M. 1993. Lithospheric buoyancy and collisional orogenesis: subduction of oceanic plateaus, continental margins, island arcs, spreading ridges and seamounts. Geological Society of America Bulletin, 105, 715-737.

DAhLEN, F.A. 1981. Isostasy and the ambient state of stress in the oceanic lithosphere. Journal of Geophysical Research B, 86, 7801-7807.

Doin, M.P. \& Fleitout, L. 1996. Thermal evolution of oceanic lithosphere: an alternative view. Earth and Planetary Science Letters, 142, 121-136.
DoRÉ, A.G. 1991. The structural foundation and evolution of Mesozoic seaways between Europe and the Arctic. Palaeogeography, Palaeoclimatology, Palaeoecology, 87, 441-492.

Doré, A.G. 1992. Synoptic palaeogeography of the Northeast Atlantic Seaway: late Permian to Cretaceous. In: PARnEll, J. (ed.) Basins on the Atlantic Seaboard: Petroleum Geology, Sedimentology and Basin Evolution. Geological Society, London, Special Publications, 62, 421-446.

Doré, A.G. \& Lundin, E.R. 1996. Cenozoic compressional structures on the NE Atlantic margin: nature, origin and potential significance for hydrocarbon exploration. Petroleum Geosciences, 2, 299-311.

Doré, A.G., Lundin, E.R., Birkeland, Ø., Eliassen, P.E. \& Jensen, L.N. 1997. The NE Atlantic Margin: implications of late Mesozoic and Cenozoic events for hydrocarbon prospectivity. Petroleum Geosciences, 3, 117-131.

Doré, A.G., Lundin, E.R., Birkeland, Ø., Eliassen, P.E. \& Jensen, L.N. 1999. Principal tectonic events in the evolution of the northwest European Atlantic margin. In: FleET, A.J. \& Boldy, S.A.R.(eds) Petroleum Geology of NW Europe: Proceedings of the 5th Conference. Geological Society, London, 1, 41-61.

DuindaM, P. \& VAN Hoorn, B. 1987. Structural evolution of the West Shetland continental margin. In: Brooks, J. \& Glennie, K.W. (eds) Petroleum Geology of North West Europe. Graham \& Trotman, London, 2, 765-773.

Eldholm, O., Gladczenko, T.P., Skogseid, J. \& Planke, S. 2000. Atlantic volcanic margins: a comparative study. In: NotTvedt, A. (ed.) Dynamics of the Norwegian Margin. Geological Society, London, Special Publications, 167, 411-428.

Eldholm, O., Myhre, A.M., Faleide, J.I., Gudlaugsson, S.T. \& Skogseid, J. 1988. Structure and evolution of passive continental margins and adjacent areas: research within the framework of the International Lithosphere Programme 1985-1987. Norges Geologiske Undersøkelse Special Publication, 3, 29-38.

Eldholm, O., Thiede, J. \& Taylor, E. 1989. Evolution of the Vøring volcanic margin. Proceedings of the Ocean Drilling Program, Scientific Results, 104. $1033-1065$.

Engelder, T. 1993. Stress Regimes in the Lithosphere. Princeton University Press, Princeton, NJ.

Fejerskov, M. \& Lindholm, C.D. 2000. Crustal stress in and around Norway: an evaluation of stress-generating mechanisms. In: Nottvedt, A. (ed.) $D y$ namics of the Norwegian Margin. Geological Society, London, Special Publications, 167, 451-467.

Fjeldskaar, W., Lindholm, C., Dehls, J.F. \& Fueldskaar, I. 2000. Postglacial uplift, neotectonics and seismicity in Fennoscandia. Quaternary Science Reviews, 19, 1413-1422.

Fleet, A. J., \& Boldy, S. A. R. (eds) 1999. Petroleum Geology of Northwest Europe: Proceedings of the 5th Conference. Geological Society, London.

Forsyth, D.W. \& UYEDA, S. 1975. On the relative importance of the driving forces of plate motion. Geophysical Journal of the Royal Astronomical Society, 43, $163-200$.

GÉLI, L. 1993. Volcano-tectonic events and sedimentation since Late Miocene times at the Mohns Ridge, near $72^{\circ} \mathrm{N}$, in the Norwegian-Greenland Sea. Tectonophysics, 222, 417-444.

Géli, L., Renard, V. \& Rommevaux, C. 1994. Ocean crust formation processes at very slow spreading centers: a model for the Mohns Ridge, near $72^{\circ} \mathrm{N}$, based on magnetic gravity, and seismic data. Journal of Geophysical Research B, 99, 2995-3013.

GibBs, A.D. 1987. Deep seismic profiles in the North Sea. In: BrooKs, J. \& Glennie, K.W. (eds) Petroleum Geology of North West Europe. Graham \& Trotman, London, 2, 1025-1028.

Grant, N., Bouma, A. \& McIntyre, A. 1999. The Turonian play in the FaeroeShetland Basin. In: FLeet, A.J. \& Boldy, S.A.R. (eds) The Fifth Conference of the Petroleum Geology of Northwest Europe. Geological Society, London, 1, 661-673.

Grevemeyer, I., Weigel, W., Whitmarsh, R.B., Avedik, F. \& Deghani, G.A. 1997. The Aegir Rift: crustal structure of an extinct spreading axis. Marine Geophysical Research, 19, 1-23.

Grunnaleite, I. \& Gabrielsen, R.H. 1995. Structure of the Møre Basin, midNorway continental margin. Tectonophysics, 252, 221-251.

Gölke, M. \& Coblentz, D. 1996. Origins of the European regional stress field. Tectonophysics, 266, 11-24.

Gölke, M., Cloetingh, S. \& Coblentz, D. 1996. Finite modelling of stress patterns along the Mid-Norwegian continental margin, $62^{\circ}$ to $68^{\circ} \mathrm{N}$. Tectonophysics, 266, 33-53.

Hamar, G.P. \& Huelle, K. 1984. Tectonic framework of the Møre Basin and the northern North Sea. In: Society, N.P. (ed.) Petroleum Geology of the North European Margin. Graham \& Trotman, London, 349-358.

Hinz, K., Dostmann, H.J. \& Hanish, J. 1982. Structural framework of the Norwegian Sea. In: The Geologic Framework and Hydrocarbon Potential of Basins in the Northern Seas. Norsk Petroleumsforening, Stavanger, 1-22.

KuvaAs, B. \& Kodaira, S. 1997. The formation of the Jan Mayen microcontinent: the missing piece in the continental puzzle between the Møre-Vøring Basins 
and East Greenland. First Break, 15, 239-247.

Lindholm, C.D., Bungum, H., Hicks, E. \& Villagran, M. 2000. Crustal stress and tectonics in the Norwegian regions determined from earthquake focal mechanisms. In: Nottvedt, A. (ed.) Dynamics of the Norwegian Margin. Geological Society, London, Special Publications, 167, 429-439.

Lundin, E.R. \& Doré, A.G. 1997. A tectonic model for the Norwegian passive margin with implications for the NE Atlantic: Early Cretaceous to break-up. Journal of the Geological Society, London, 154, 545-550.

Lundin, E.R. \& DorÉ, A.G. 2001. Mid-Cenozoic post-breakup deformation in the 'passive' margins bordering the Norwegian-Greenland Sea. Marine and Petroleum Geology, 20, 1-15.

Mosar, J. 2000. Depth of the extensional faulting on the Mid-Norway Atlantic passive margin. Norges Geologiske Undersøkelse Bulletin, , 437.

Mosar, J., Osmundsen, P.T., Sommaruga, A. \& Torsvik, T.H. 2001a. The MidNorway Atlantic Passive Margin. EUG XI, Journal of Conference Abstracts, 6, 726.

Mosar, J., Torsvik, T.H., Eide, E.A., Sommaruga, A. \& Osmundsen, P.T. 2001b. Separating Norway and Greenland: drifting plates and stretched margins. Geonytt, Program \& Sammendrag, , 82.

Müller, R.D., Gaina, C., Roest, W.R. \& Lundbeck Hansen, D. 2001. A recipe for microcontinent formation. Geology, 29, 203-206.

Müller, R.D., Royer, J.Y. \& LAWver, L.A. 1993. Revised plate motions relative to the hotspots from combined Atlantic and Indian Ocean hotspot tracks. Geology, 21, 275-278.

Nøttvedt, A. (ed.) 2000. Dynamics of the Norwegian Margin. Geological Society, London, Special Publications, 167.

Olesen, O., Torsvik, T.H., Tveten, E., Zwann, K.B., Løseth, H. \& HenningSEN, T. 1997. Basement structure of the continental margin in the LofotenLopphavet area, northern Norway: constraints from potential field data, onland structural mapping and paleomagnetic data. Norsk Geologisk Tidsskrift, 77, $15-30$.

PArker, J. R. (ed.) 1993. Petroleum Geology of Northwest Europe: Proceedings of the 4th Conference. Geological Society, London.

Pascal, C. \& Gabrielsen, R.H. 2001. Numerical modeling of Cenozoic stress patterns in the mid-Norwegian margin and northern North Sea. Tectonics, 20, $585-599$.

Pharaoh, T.C. 1999. Palaeozoic terranes and their lithospheric boundaries within the Trans-European Suture Zone (TESZ): a review. Tectonophysics, 314, $17-41$.

Reemst, P. \& Cloetingh, S. 2000. Polyphase rift evolution of the Vøring margin (mid-Norway): constraints from forward tectonstratigraphic modeling. Tectonics, 19, 225-240.

SancheZ-Ferrer, F., James, S.D., LaK, B. \& Evans, A.M. 1999. Techniques used in the exploration of turbidite reservoirs in a frontier setting-Helland Hansen licence, Vøring Basin, offshore mid Norway. In: FleEt, A.J. \& Boldy, S.A.R. (eds) Petroleum Geology of NW Europe: Proceedings of the 5th Conference. Geological Society, London, 1, 281-292.

Skogseid, J. 1994. Dimensions of the Late Cretaceous-Paleocene northeast Atlantic rift derived from Cenozoic subsidence. Tectonophysics, 240, $225-247$.

Skogseid, J. \& Eldholm, O. 1987. Early Cenozoic crust at the Norwegian continental margin and the conjugate Jan Mayen Ridge. Journal of Geophysical Research B, 92, 11471-11491.

Skogseid, J., Pedersen, T., Eldholm, O. \& Larsen, B.T. 1992a. Tectonism and magmatism during NE Atlantic continental break-up: the Vøring Margin. In: Storey, B.C., Alabaster, T. \& Pankhurst, R.J. (eds) Magmatism and the Causes of Continental Break-up. Geological Society, London, Special Publications, 68, 305-320.

Skogseid, J., Pedersen, T. \& Larsen, B.T. 1992a. Vøring Basin: subsidence and tectonic evolution. In: Larsen, R.M., BrekKe, H., Larsen, B.T. \& Tallerans, E. (eds) Tectonic Modelling and its Application to Petroleum Geology. Norwegian Petroleum Society, Special Publication, 1, 55-82.

Skogseid, J., Planke, S., Faleide, J.I., Pedersen, T., Eldholm, O. \& Neverdal, F. 2000. NE Atlantic continental rifting and volcanic margin formation. In: Nottvedt, A. (ed.) Dynamics of the Norwegian Margin. Geological Society, London, Special Publications, 167, 295-326.

Smallwood, J.R., Towns, M.J. \& White, R.S. 2001. The structure of the FaeroeShetland Trough fron integrated deep seismic and potential field modelling. Journal of the Geological Society, London, 158, 409-412.

Spencer, A.M., Birkeland, Ø., KnaG, G.Ø. \& Fredsted, R. 1999. Petroleum systems of the Atlantic margin of northwest Europe. In: FLeET, A.J. \& Boldy, S.A.R. (eds) Petroleum Geology of NW Europe: Proceedings of the 5th Conference. Geological Society, London, 1, 231-246.

SRIVAstava, S.P. \& TAPSCOTT, C.R. 1986. Plate kinematics of the North Atlantic. In: Vogt, P.R. \& Tucholke, B.E. (eds) The Western North Atlantic Region. Geological Society of America, Boulder, CO, M, 379-404.

Stein, C.A. \& Stein, S. 1992. A model for the global variation in oceanic depth and heat flow with lithospheric age. Nature, 359, 123-129.

Stein, S., Cloetingh, S., Sleep, N.H. \& Wortel, R. 1989. Passive margin earthquakes, stresses and rheology. In: Gregersen, S. \& Basham, P.W. (eds) Earthquakes at North Atlantic Passive Margins: Neotectonics and Postglacial Rebound. Kluwer, Dordrecht, 231-259.

Stein, S., Melosh, H.J. \& Minster, J.B. 1977. Ridge migration and asymetric sea-floor spreading. Earth and Planetary Science Letters, 36, 51-62.

Stuevold, L.M., Skogseid, J. \& Eldholm, O. 1992. Post-Cretaceous uplift events on the Vøring continental margin. Geology, 20, 919-922.

Swiecicki, T., GibBs, P.B., FArrow, G.E. \& Coward, M.P. 1998. A tectonostratigraphic framework for the Mid-Norway region. Marine and Petroleum Geology, 15, 245-276.

Torske, T. \& PrestviK, T. 1991. Mesozoic detachment faulting between Greenland and Norway: inferences from Jan Mayen fracture zone system and associated alkalic volcanic rocks. Geology, 19, 481-484.

Torsvik, T.H. \& Smethurst, M.A. 1999. Plate tectonic modeling: virtual reality with GMAP. Computers and Geosciences, 25, 395-402.

Torsvik, T.H., Mosar, J. \& EIDE, E.A. 2001a. Cretaceous-Tertiary geodynamics: a North Atlantic exercise. Geophysical Journal International, 146, 850-866.

Torsvik, T.H., Van der Voo, R., Meert, J.G., Mosar, J. \& Walderhaug, H.J. 2001b. Reconstructions of continents around the North Atlantic at about the 60th parallel. Earth and Planetary Science Letters, 187, 55-69.

Turcotte, D.L. \& Schubert, G. 1982. Geodynamics: Application of Continuum Mechanics to Geological Problems. New York.

Vågnes, E., Gabrielsen, R.H. \& Haremo, P. 1998. Late Cretaceous-Cenozoic intraplate contractional deformation at the Norwegian continental shelf: timing, magnitude and regional implications. Tectonophysics, 300, 29-46.

van Wijk, J.W., Huismans, R.S., ter Voorde, M. \& Cloetingh, S.A.P.L. 2001. Melt generation at volcanic continental margins: no need for mantle plumes?. Geophysical Research Letters, 28, 3995-3998.

VINK, G.E. 1984. A hotspot model for Iceland and the Vøring Plateau. Journal of Geophysical Research B, 89, 9949-9959.

Vogt, P.R. 1986a. Geophysical and geochemical signatures and plate tectonics. In: Hurdle, B.G. (ed.) The Nordic Seas. Springer, Berlin, 413-663.

VoGT, P.R. 1986b. Seafloor topography, sediments, and paleoenvironments. In: Hurdle, B.G. (ed.) The Nordic Seas. Springer, Berlin, 237-412.

Walker, I.M., Berry, K.A., Bruce, J.R., Bystøl, L. \& Snow, J.H. 1997. Structural modelling of regional depth profiles in the Vøring Basin: implications for the structural and stratigraphic development of the Norwegian passive margin. Journal of the Geological Society, London, 154, $537-544$.

WDowINSKI, S. 1998. A theory of intraplate tectonics. Journal of Geophysical Research B, 103, 5037-5059.

Wilson, M. 1993. Plate-moving mechanisms: constraints and controversies. Journal of the Geological Society, London, 150, 923-926.

Ziegler, P. A. 1988. Evolution of the Arctic-North Atlantic and the Western Tethys. American Association of Petroleum Geologists, Memoir, 43.

ZIEGLER, P.A. 1989. Geodynamic model for alpine intra-plate compressional deformation in Western and Central Europe. In: Cooper, M.A. \& WiLliams, G.D. (eds) Inversion Tectonics. Geological Society, London, Special Publications, 44, 63-85.

ZIEGLER, P.A. 1993. Plate-moving mechanisms: their relative importance. Journal of the Geological Society, London, 150, 927-940.

Ziegler, P.A., Cloetingh, S. \& van Wees, J.-D. 1995. Dynamics of intra-plate compressional deformation: the Alpine foreland and other examples. Tectonophysics, 252, 7-59.

Ziegler, P.A., Cloetingh, S., Guiraud, R. \& Stampfli, G.M. 2001. Peri-Tethyan platforms: contraints on dynamics of rifting and basin inversion. In: Cavazza, W., Robertson, A.H.F. \& Ziegler, P.A. (eds) Peritethyan Rift/ Wrench Basins and Passive Margins. IGCP 369, Bulletin du Muséum National d'Histoire Naturelle, 186, 9-49.

Ziegler, P.A., van Wees, J.D. \& Cloetingh, S. 1998. Mechanical controls on collision-related compressional intraplate deformation. Tectonophysics, 300, $103-129$.

ZоваCK, M.L. 1992. First- and second-order patterns of stress in the lithosphere: the World Stress Map project. Journal of Geophysical Research B, 97, $11703-11728$. 